University of Nebraska - Lincoln

DigitalCommons@University of Nebraska - Lincoln

2005

\title{
The incidence of genotypes at codon 171 of the prion protein gene (PRNP) in five breeds of sheep and production traits of ewes associated with those genotypes
}

\author{
B. M. Alexander \\ University of Wyoming \\ R. H. Stobart \\ University of Wyoming \\ W. C. Russell \\ University of Wyoming \\ Katherine I. O'Rourke \\ U.S. Department of Agriculture, katherine.orourke@ars.usda.gov \\ G. S. Lewis \\ U.S. Sheep Experiment Station \\ See next page for additional authors \\ Follow this and additional works at: https://digitalcommons.unl.edu/zoonoticspub \\ Part of the Veterinary Infectious Diseases Commons
}

Alexander, B. M.; Stobart, R. H.; Russell, W. C.; O'Rourke, Katherine I.; Lewis, G. S.; Logan, J. R.; Duncan, J. V.; and Moss, G. E., "The incidence of genotypes at codon 171 of the prion protein gene (PRNP) in five breeds of sheep and production traits of ewes associated with those genotypes" (2005). Other

Publications in Zoonotics and Wildlife Disease. 112.

https://digitalcommons.unl.edu/zoonoticspub/112

This Article is brought to you for free and open access by the Wildlife Disease and Zoonotics at DigitalCommons@University of Nebraska - Lincoln. It has been accepted for inclusion in Other Publications in Zoonotics and Wildlife Disease by an authorized administrator of DigitalCommons@University of Nebraska - Lincoln. 


\section{Authors}

B. M. Alexander, R. H. Stobart, W. C. Russell, Katherine I. O'Rourke, G. S. Lewis, J. R. Logan, J. V. Duncan, and G. E. Moss 


\title{
The incidence of genotypes at codon 171 of the prion protein gene (PRNP) in five breeds of sheep and production traits of ewes associated with those genotypes ${ }^{1,2}$
}

\author{
B. M. Alexander*3, R. H. Stobart*, W. C. Russell*, K. I. O’Rourke $\dagger$, G. S. Lewis \\ J. R. Logan§, J. V. DuncanI, and G. E. Moss* \\ *University of Wyoming, Laramie 82071; †USDA-ARS, Pullman, WA 99164; \\ $\ddagger$ U.S. Sheep Experiment Station, Dubois, ID 83423; §Wyoming Livestock Board, Cheyenne 82009; \\ and IIUSDA-Animal Plant Health Inspection Service, Casper, WY 82604
}

\begin{abstract}
Scrapie is one of several transmissible spongiform encephalopathies of livestock. Disease susceptibility is linked to polymorphisms in the normal prion protein gene that encodes the mammalian prion precursor. Codon 171 of this gene is a major determinant of scrapie susceptibility. Selection for arginine (R) at codon 171 is encouraged by the USDA to decrease the incidence of scrapie. Objectives of this study were to determine the frequency of $R$ allele variants at codon 171 in a sample of sheep from five breeds (Columbia, Hampshire, Rambouillet, Suffolk, and Targhee) and western white-faced commercial ewes and to determine whether the $\mathrm{R}$ allele is associated with ewe and lamb production traits. Genotyping was performed on 532 ewes and 901 lambs from the University of Wyoming flock, in addition to 820 rams from 52 sheep producers from Wyoming and surrounding areas, using a DNA mismatch assay that discriminated the $\mathrm{R}$ allele from others at codon 171. Genotyping was performed by DNA sequencing on 127 rams representing all breeds, except Hampshire from the USDA Sheep Experiment Station at Dubois, ID. The 171R allele was found in all five breeds and in the commercial western white-faced ewes. Genotype frequencies varied $(P<0.001)$ by breed
\end{abstract}

in ewe and ram populations. Influence of R-allele frequency on ewe lambing records and individual lamb records was analyzed for Columbia (62, 161, 121), Hampshire (89, 193, 162), Rambouillet (87, 179, 133), Suffolk $(67,178,161)$, and commercial sheep $(227,463$, 324 ) for numbers of ewes, total number of ewe production records, and individual lamb records, respectively. Suffolk ewes without the $\mathrm{R}$ allele (non- $R /$ non- $R$ ) gave birth to more $(P \leq 0.005)$ multiple lambs than heterozygous non- $R$ / $R$ ewes. Homozygous non- $R$ / non-R Suffolk ewes weaned lighter $(P=0.02)$ individual lambs but more $(P=0.03)$ total weight of lamb than heterozygous $n o n-R / R$ ewes. Although ewes genotyped homozygous $n o n-R / n o n-R$ or heterozygous non- $R / R$ at codon 171 from the commercial flock gave birth to more $(P \leq 0.002)$ multiple lambs than ewes genotyped $R / R$, differences were not detected $(P=0.14)$ in total weight of lamb weaned. Production traits of Columbia, Hampshire, and Rambouillet ewes did not differ $(P \geq 0.08)$ by ewe genotype. Lamb birth and weaning weights were not influenced $(P \geq 0.12)$ by lamb genotype in any of the breeds or in the commercial flock. In this population, ultimate lamb production was only influenced by genotype at codon 171 in the Suffolk flock.

Key Words: Codon 171, Genotype, Productivity, Scrapie, Sheep

(2005 American Society of Animal Science. All rights reserved.

J. Anim. Sci. 2005. 83:455-459

\section{Introduction}

Scrapie was first detected in sheep and goats in the United States in 1947 and is now endemic in many states (Wineland et al., 1998). Scrapie is a transmissible

\footnotetext{
${ }^{1}$ Mention of trade names or commercial products in this article is solely for the purpose of providing specific information and does not imply recommendation or endorsement by the USDA. Supported in part by a grant from the ARS, USDA (CWU 5348-32000-011-00D).

${ }^{2}$ We thank M. Rock for genotyping assistance.
}

spongiform encephalopathy (TSE), a group of diseases comprising bovine spongiform encephalopathy and a number of human disorders of diverse origins. Although scrapie is not known to be transmitted to humans from sheep or goats, the apparent transmission of bovine

\footnotetext{
${ }^{3}$ Correspondence: Dept. of Animal Science, P.O. Box 3684, Laramie 82071 (phone: 307-766-5374; fax: 307-766-2355; e-mail: balex@ uwyo.edu).

Received June 3, 2004.

Accepted November 22, 2004.]
} 
spongiform encephalopathy to humans in the United Kingdom (Bruce et al., 1997) resulted in a call for the eradication of all TSE in food-producing animals.

The major causative agent of all TSE is a proteaseresistant isoform of the normal mammalian cellular prion protein precursor (Prusiner, 1982). Variations at codons 171, 154, and 136 of the prion protein (PRNP) are known to affect scrapie susceptibility. Variants at codon 171 code for arginine $(\mathbf{R})$, glutamine $(\mathbf{Q})$, histidine, or lysine. Sheep with at least one $\mathrm{R}$ at codon 171 are rarely susceptible to scrapie (Westaway et al., 1994; O'Rourke et al., 1996). Current Animal and Plant Health Inspection Services (APHIS) policy allows producers with infected flocks to retain or move most sheep possessing at least one allele for 171R (APHIS, 2001). Although AA substitutions at codon 136 and 154 may also affect scrapie susceptibility, current recommendations of the National Institute for Animal Agriculture (NIAA, 2004) only make use of genotyping at codon 171 as a preventive tool for scrapie infection.

Therefore, objectives of the present study were to study the incidence of the $R$ allele at codon 171 in breeds typical of Western production flocks and to determine whether differences in production traits of ewes and lambs within those breeds in a single flock were associated with the presence or absence of the $R$ variant at codon 171 .

\section{Materials and Methods}

\section{Sheep}

Genotypes were determined for 1,479 mature sheep and 901 lambs. Rams (Suffolk, $\mathrm{n}=217$; Hampshire, $\mathrm{n}=176$; Rambouillet, $\mathrm{n}=415$; Columbia, $\mathrm{n}=52$; and Targhee, $\mathrm{n}=87$ ) from independent sheep producers in Wyoming and the surrounding areas, including the U.S. Sheep Experiment Station in Dubois, ID (USSES), as well as purebred ewes (Columbia, $\mathrm{n}=62$; Hampshire, $\mathrm{n}=89$; Suffolk, $\mathrm{n}=67$; Rambouillet, $\mathrm{n}=87$ ) and 227 commercial western white-faced ewes from the University of Wyoming Animal Science Department experimental flock were sampled. Analysis of lambing records from the University of Wyoming ewes included data from Columbia ( $\mathrm{n}=161$ records; $\mathrm{n}=93$ non- $R /$ non- $R$, $\mathrm{n}=66$ non $-R / R$, and $\mathrm{n}=2 R / R)$; Hampshire $(\mathrm{n}=193$ records; $\mathrm{n}=64$ non- $R /$ non $-R, \mathrm{n}=107$ non $-R / R$, and $\mathrm{n}=22 R / R$ ); Rambouillet ( $\mathrm{n}=179$ records; $\mathrm{n}=3$ non$R /$ non $-R, \mathrm{n}=61$ non- $R / R$, and $\mathrm{n}=115 R / R$ ); Suffolk ( $\mathrm{n}=178$ records; $\mathrm{n}=124$ non $-R /$ non- $R, \mathrm{n}=47$ non- $R$ / $R$, and $\mathrm{n}=7 R / R$ ), and western white-faced commercial ( $\mathrm{n}=463$ records; $\mathrm{n}=173$ non $-R /$ non $-R, \mathrm{n}=250$ non$R / R$, and $\mathrm{n}=40 R / R$ ) ewes. Lambs from the University of Wyoming purebred Columbia ( $\mathrm{n}=121)$, Hampshire $(\mathrm{n}=162)$, Rambouillet $(\mathrm{n}=133)$, and Suffolk $(\mathrm{n}=161)$ flocks in addition to lambs from the commercial $(\mathrm{n}=$ 324) flock were genotyped and individual production records analyzed.

\section{PRNP Genotyping}

Blood was collected by jugular venipuncture into EDTA-coated Vacutainer (Becton Dikinson Co., Franklin Lakes, NJ) tubes. Genotypes of rams from the USSES (Columbia, $\mathrm{n}=22$; Suffolk, $\mathrm{n}=26$; Rambouillet, $\mathrm{n}=46$; and Targhee, $\mathrm{n}=33$ ) were determined by DNA sequence analysis. Briefly, DNA was prepared from buffy coat cells using a commercial kit (Puregene, Gentra Systems, Inc., Minneapolis, MN) following the manufacturer's instructions. The open reading frame of the $P R N P$ gene was amplified using upstream $\left(5^{\prime}\right.$ ggc att tga tgc tga cac c) and downstream (5' tac agg gct gca ggt aga c) primers flanking the open reading frame (Westaway et al., 1994). Products from the PCR were purified by Exo/SAP (USB Corp., Cleveland, $\mathrm{OH}$ ) to remove unincorporated dNTP and primers, and then sequenced on the ABI Prism 377 DNA sequencer (Applied Biosystems, Inc., Foster City, CA) with Big Dye Terminator chemistry (Applied Biosystems, Inc.) using a forward (5' gccaaccgetatccacctca) and a reverse (5' ggtggtgactgtgtgttgcttga 3') primer (Amplicon Express, Pullman, WA).

University of Wyoming ewes, lambs, and rams from other producers were genotyped using a DNA mismatch binding assay (Debbie et al., 1997) by an APHIS-approved commercial laboratory (GeneCheck, Inc., Fort Collins, CO). This assay does not distinguish between sequences encoding $\mathrm{Q}$, histidine, or lysine. Histidine and lysine are considered equivalent to $\mathrm{Q}$ for scrapie resistance in the United States regulatory program (NIAA, 2004), and all are referred to as non- $R$ in the present manuscript.

Differences in R-allele frequencies among breeds in the ram and ewe populations were analyzed by $\chi^{2}$ analysis of SAS (Ver. 8.1; SAS Inst., Inc., Cary, NC). Genotypes within breeds were further analyzed to determine any differences between the ram and ewe populations.

\section{Effect of the $R$ Allele on Production Traits of Ewes}

Historic lambing records birth weight, and average and total adjusted weaning weight of lamb weaned per ewe weaning from the Wyoming purebred ewes were analyzed within breed to evaluate for differences due to R-allele frequencies using the GLM methods of SAS. For most years, a single sire per breed predominated; therefore, the effect of sire was removed by nesting sire within year in the statistical model. Ewe age and lambing year were included in the model. Individual sires were not known for the commercial ewes; therefore, sire breed type was used in the model. The potential interaction of sire with ewe genotype was initially included in the model, but was removed from the final analysis due to lack of fit. Birth-type data were classified as either single or multiple and analyzed using $\chi^{2}$ analysis of SAS. Because the Columbia and Suffolk ewe flock had few production records $(\mathrm{n}=2$ and 7 , respectively) from ewes genotyped $R / R$, these breeds 
Table 1. Frequency and proportion (\%) of genotypes of rams from 52 producer flocks from Wyoming and surrounding areas and the U.S. Sheep Experiment Station (USSES)

\begin{tabular}{|c|c|c|c|c|c|c|c|c|}
\hline \multirow[b]{2}{*}{ Breed } & \multicolumn{4}{|c|}{ Producer rams ${ }^{\mathrm{a}}$} & \multicolumn{4}{|c|}{ USSES rams $^{\mathrm{b}}$} \\
\hline & $\mathrm{n}$ & Non- $R$ & Non- $R / R$ & $R / R$ & $\mathrm{n}$ & $Q / Q$ & $Q / R$ & $R / R$ \\
\hline Columbia $^{x}$ & 30 & $16(53.3)$ & $14(46.7)$ & 0 & 22 & $12(54.5)$ & 7 (31.8) & $3(13.6)$ \\
\hline Suffolk $^{\mathrm{y}, \mathrm{z}}$ & 191 & $50(26.2)$ & $92(48.2)$ & $49(25.6)$ & 26 & $4(15.4)$ & $14(53.8)$ & $8(30.8)$ \\
\hline Rambouillet $^{\mathrm{z}}$ & 369 & $84(22.8)$ & $158(42.8)$ & $135(36.6)$ & 46 & $10(21.7)$ & $28(60.9)$ & $8(17.4)$ \\
\hline Hampshire $^{\mathrm{w}, \mathrm{y}}$ & 176 & $57(32.4)$ & $80(45.5)$ & $39(22.2)$ & 0 & - & - & - \\
\hline Targhee $^{\mathrm{w}, \mathrm{x}}$ & 54 & $29(53.7)$ & $22(40.7)$ & $3(0.6)$ & 33 & $9(27.3)$ & $17(51.5)$ & $7(21.2)$ \\
\hline
\end{tabular}

\footnotetext{
${ }^{a}$ There was no distinction made between glutamine $(\mathrm{Q})$, histidine $(\mathrm{H})$, or lysine $(\mathrm{K})$ at codon 171 ; all are reported as non-R. The National Institute for Animal Agriculture considers sheep with $\mathrm{H}$ and $\mathrm{K}$ at codon 171 to be equivalent in scrapie susceptibility to $Q$.

${ }^{\mathrm{b}}$ Genotypes of rams from the USSES were determined by DNA sequence analysis.

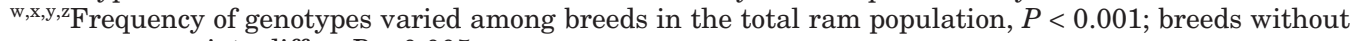
common superscripts differ, $P<0.005$.
}

were subsequently reanalyzed using production records from ewes genotyped homozygous non- $R /$ non- $R$ or heterozygous non- $R / R$ at codon 171 only. In addition, the Rambouillet ewe flock had too few $(\mathrm{n}=3)$ production records from ewes genotyped non-R/non-R; therefore, the Rambouillet production data were subsequently reanalyzed with lambing records from those ewes removed from the data set.

\section{Production Traits of Lambs with Differing Prion Protein Genotypes}

Effect of lamb genotype on individual lamb performance was analyzed within breed using GLM methods of SAS. Dam age, lamb sex, birth-type and year were included in the model for analysis of birth weight, with rearing-typed added to the model for analysis of adjusted weaning weight. Effect of sire was removed by nesting sire within year. Individual sires were not known for the commercial lambs; therefore, parental breed type was included in the final model for the commercial lambs.

\section{Results and Discussion}

\section{Prion Protein Genotypes at Codon 171 in Breeds Typical to Western Sheep Production}

The three major reported diploid genotypes (non- $R /$ $n o n-R, n o n-R / R$, and $R / R$ ) were found in all five breeds and in western white-faced commercial sheep (Table 1 ). An allele encoding $171 \mathrm{~K}$, recently observed in several breeds of sheep in China (Gombojav et al., 2003) and in Barbados sheep in the United States (K. I. O'Rourke, unpublished data), was not observed in the sample of rams from the USSES $(n=127)$.

The distribution of the prion protein alleles varies among flocks depending on the genetics of founder and breeding stock, but general trends were noted among breeds in the United Kingdom, Europe, and Scandinavia (Dawson et al., 1998; Thorgeirsdottir et al., 1999). Including rams from the USSES, the frequency of al- leles at codon 171 differed $(P<0.001)$ by breed in the ram population; genotype frequencies of both populations are reported in Table 1 . In the total ram population, Columbia and Targhee breeds had the highest percentage of rams genotyped homozygous non-R/non$R$ (53.8 and $43.7 \%$, respectively). Hampshire and Suffolk were intermediate, with 32.4 and $24.9 \%$ genotyped $n o n-R /$ non- $R$, respectively. Rambouillet had the fewest numbers of rams genotyped non-R/non-R at $22.7 \%$, but only tended $(P=0.1)$ to differ from the Suffolk ram population.

Genotype frequencies also varied $(P<0.001)$ among the breeds of the University of Wyoming ewe flocks (Table 2). Within the ewe population, genetic profiles at codon 171 did not differ $(P=0.39)$ between Columbia and Suffolk ewes, and these two breeds had the greatest percentage of ewes genotyped homozygous non-R/non$R$ (59.7 and $61.2 \%$, respectively; Table 2 ). The incidence of ewes genotyped non- $R$ / non- $R$ were intermediate and genotype profiles did not differ $(P=0.45)$ between Hampshire and western white-faced commercial ewes. Rambouillet ewes had the highest incidence of ewes with the $R$ allele, with $97.7 \%$ of ewes genotyped homozygous $R / R$ or heterozygous non- $R / R$ at codon 171 .

Genotype profiles of the University of Wyoming Columbia and Hampshire ewes did not differ $(P \geq 0.10)$ from the analogous ram population, but differences $(P$ $<0.001$ ) in genotype profiles were noted between the ewe and ram population in the other breeds. Through production selection, it seems the University of Wyoming Suffolk flock was naively selected for non- $R$ alleles at codon 171. Conversely, Rambouillet ewes in the University of Wyoming flock had a greater $(P<0.001)$ incidence of animals genotyped $R / R$ than the ram population (62.1 vs. $34.5 \%$, respectively). The ram and ewe populations of the Columbia breed had a high incidence of animals that were genotyped homozygous non-R/ $n o n-R$. Although this breed has not been historically associated with scrapie (Wineland, 1998), this apparent contradiction may be due to the extensive management systems common to white-faced sheep, which could hamper detection of infected animals or actually de- $\square$ 
Table 2. Frequency and proportion (\%) of genotypes of ewes and lambs from the University of Wyoming purebred and western white-faced commercial flocks ${ }^{\mathrm{a}}$

\begin{tabular}{|c|c|c|c|c|c|c|c|c|}
\hline \multirow[b]{2}{*}{ Breed } & \multicolumn{4}{|c|}{ Ewes $^{b}$} & \multicolumn{4}{|c|}{ Lambs } \\
\hline & $\mathrm{n}$ & Non- $R$ & Non- $R / R$ & $R / R$ & $\mathrm{n}$ & Non- $R$ & Non- $R / R$ & $R / R$ \\
\hline Columbia $^{x}$ & 62 & $37(59.7)$ & 24 (38.7) & $1(1.6)$ & 121 & $35 \quad(28.9)$ & $78(64.5)$ & $8(6.6)$ \\
\hline Suffolk $^{\mathrm{x}}$ & 67 & $41(61.2)$ & $22(32.8)$ & $4(6.0)$ & 161 & $53(32.9)$ & $89(55.3)$ & 19 (11.8) \\
\hline Rambouillet $^{\mathrm{z}}$ & 87 & $2(2.3)$ & $31(35.6)$ & $54(62.1)$ & 133 & - & $12(9.0)$ & $121(91.0)$ \\
\hline Hampshire ${ }^{\mathrm{y}}$ & 89 & $26(29.2)$ & $51(57.3)$ & $12(13.5)$ & 162 & $34(21.0)$ & $80(49.4)$ & 48 (29.6) \\
\hline Commercial $^{\mathrm{y}}$ & 227 & $49(21.5)$ & $132(58.1)$ & $46(20.3)$ & 324 & $93(28.7)$ & $177(54.6)$ & 54 (16.7) \\
\hline
\end{tabular}

\footnotetext{
aThere was no distinction made between glutamine $(\mathrm{Q})$, histidine $(\mathrm{H})$, or lysine $(\mathrm{K})$ at codon 171 ; all are reported as non-R. The National Institute for Animal Agriculture (NIAA) considers sheep with H and K at codon 171 to be equivalent in scrapie susceptibility to $Q$.

${ }^{b}$ Frequency of genotypes varied $(P<0.001)$ among breeds in the ewe population. The frequency of genotypes was not analyzed in the lamb population.

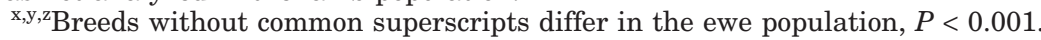

crease the opportunity for transmission of scrapie compared with the more intensive management systems frequently used for black-faced breeds. Evaluation of records from the USDA scrapie control and eradication program from 1947 through 1992 showed that Suffolk (87\%) and Hampshire (6\%) were the breeds most commonly affected with scrapie (Wineland et al., 1998).

\section{Production Traits of Ewes with Differing Genotypes at Codon 171}

Scrapie resistance of a flock can be improved by selectively breeding resistant animals (Arnold et al., 2002; Smit et al., 2002). The acceptability of eradication of scrapie through the selection of genetically resistant breeding stock depends on identification of real or perceived production advantages possessed by scrapie-susceptible animals. In this study, Suffolk ewes genotyped

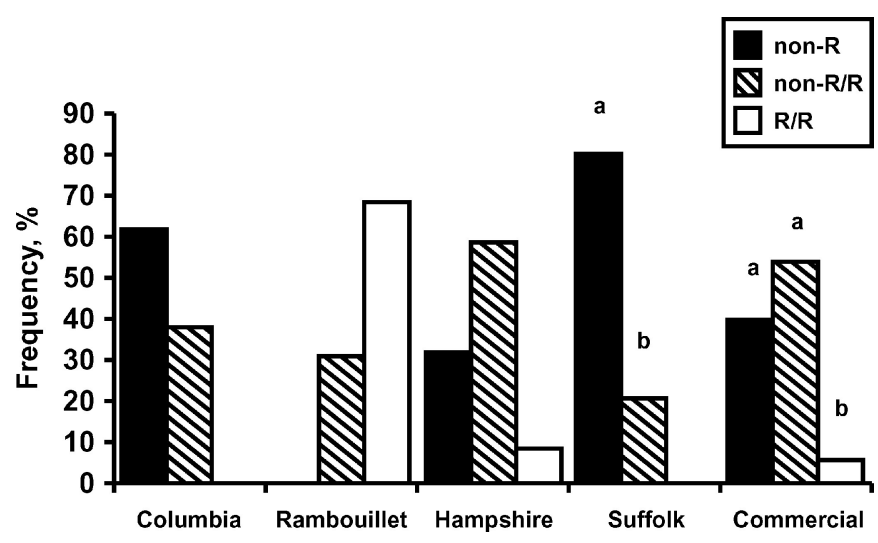

Figure 1. Frequency of multiple births from ewes with genotypes non-R/non-R, non- $R / R$, and $R / R$ at codon 171 within breed. Prolificacy differed by genotype in the Suffolk $(P=0.005)$ and Commercial $(P<0.001)$ ewe flock. ${ }^{a, b}$ Columns without common superscripts differ within breed, $P \leq 0.005$. Differences in prolificacy were not detected in the University of Wyoming Columbia $(P=0.19)$, Rambouillet $(P=0.31)$, or Hampshire $(P=0.22)$ flocks. homozygous non- $R /$ non- $R$ gave birth to more $(P=$ 0.005 ) multiple lambs per ewe lambing than heterozygous $($ non- $R / R$ ) ewes (Figure 1$)$. As expected, total birth weight $(P<0.001)$ and weight of lamb weaned $(P=$ $0.03)$ differed between genotypes at codon 171. Ewes genotyped non- $R$ / non- $R$ gave birth to more $(P<0.001)$ total weight $(11.6 \pm 0.4 \mathrm{~kg})$ of lamb than did those genotyped non- $R / R(8.9 \pm 0.7 \mathrm{~kg})$ at codon 171 . Total $(P=0.03$; Figure 2$)$ and average $(P=0.02)$ weight of lamb weaned also differed by ewe genotype at codon 171 . Ewes genotyped non- $R /$ non $-R$ weaned lighter $(P=$ $0.02 ; 38.8 \pm 0.7$ vs. $41.5 \pm 1.2 \mathrm{~kg}$ ) individual lambs but more $(P=0.03)$ total weight of lamb than those genotyped non- $R / R$ at codon 171 (Figure 2). Prolificacy also differed $(P<0.001)$ by ewe genotype in the commercial ewe flock (Figure 1). Commercial ewes genotyped $R / R$ gave birth to fewer $(P \leq 0.002)$ multiple lambs than ewes genotyped non- $R / R$ or non-R/non-R. Total birth weight $(P=0.11)$ or weaning weight $(P=0.14$; Figure 2), however, did not differ by genotype. Similar associations of genotype with birth-rate $(P \geq 0.20$; Figure 1), total birth weight ( $P \geq 0.08)$, individual weaning weight $(P \geq 0.27)$, or total weight of lambs weaned ( $P$

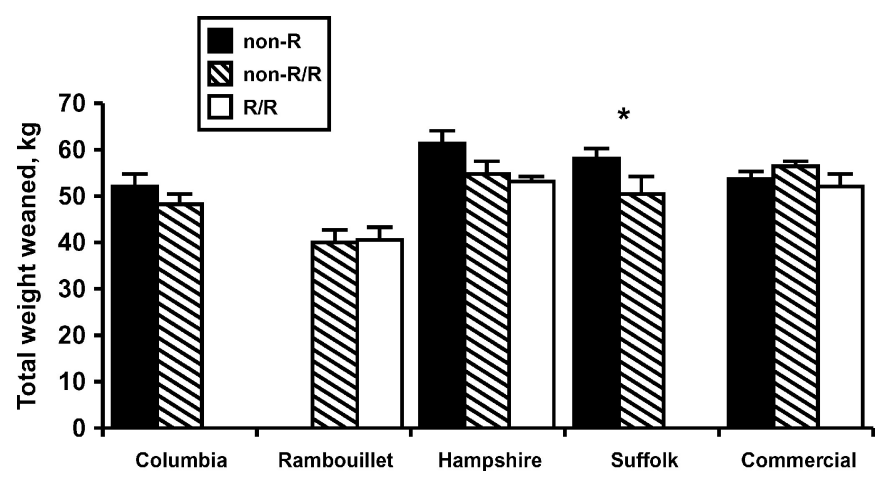

Figure 2. Total weight of lamb weaned $(\mathrm{kg})$ from ewes with genotypes non-R/non- $R$, non- $R / R$, and $R / R$ at codon 171 within breed. *Quantity of lamb weaned differed between genotypes in the Suffolk breed, $P \leq 0.03$. 
$\geq 0.14$; Figure 2) were not detected in any of the other breeds.

\section{Production Traits of Lambs with Differing \\ Prion Protein Genotypes}

Individual lamb birth weight $(P \geq 0.22)$ or adjusted weaning weight $(P \geq 0.12)$ did not differ among lambs genotyped homozygous non-R/non- $R$, heterozygous non- $R / R$, and homozygous $R / R$ in any of the breeds or in the commercial flock (data not shown). Distributions of genotypes of lambs within breed are listed in Table 2 . Incidence of the R allele at codon 171 (Table 2) seemed to be greater in Columbia, Rambouillet, and Suffolk lambs compared with their maternal ewe flock (Table 2 ). This increase was most likely due to selecting flock sires with at least one $\mathrm{R}$ allele. Distribution of the $\mathrm{R}$ allele in the Hampshire and commercial lambs was similar to what might be predicted when there is an abundance of heterozygous non- $R / R$ genotypes in the flock.

In conclusion, $\mathrm{R}$ was identified at codon 171 in all five prominent breeds of sheep and western white-faced commercial ewes. Under the husbandry conditions of the University of Wyoming flock, Suffolk ewes genotyped homozygous non- $R /$ non- $R$ gave birth to more lambs and weaned more total weight of lamb than ewes genotyped heterozygous non- $R / R$. Performance differences were not noted among lamb genotypes in the Suffolk breed. Although ewes in the commercial flock with an $R / R$ genotype gave birth to fewer multiple lambs, differences were not detected in quantity of lamb weaned. In the other breeds, there were no production advantages for ewes or lambs genotyped non-R/non- $R$.

\section{Implications}

Under current USDA guidelines, animals with at least one allele containing arginine are considered resistant to most strains of scrapie. Selection for the arginine allele, as per NIAA guidelines, should not exert deleterious effects on ultimate lamb production in Co- lumbia, Hampshire, Rambouillet, or western whitefaced commercial flocks.

\section{Literature Cited}

APHIS USDA Animal Plant Health Inspection Service. 2001. Scrapie in sheep and goats: Interstate movement restrictions and indemnity program. Final Rule. Federal Register 66(162):4369444003.

Arnold, M., C. Meek, C. R. Webb, and L. J. Hoinville. 2002. Assessing the efficacy of a ram-genotyping programme to reduce susceptibility to scrapie in Great Britain. Prev. Vet. Med. 56:227-249.

Bruce, M. E., R. G. Will, J. W. Ironside, I. McConnell, D. Drummond, A. Suttle, L. McCardie, A. Chree, J. Hope, C. Birkett, S. Cousens, H. Fraser, and C. J. Bostock. 1997. Transmissions to mice indicate that 'new variant' CJD is caused by the BSE agent. Nature 389:498-501.

Dawson, M., L. J. Hoinville, B. D. Hosie, and N. Hunter. 1998. Guidance on the use of PrP genotyping as an aid to the control of clinical scrapie. Vet. Rec. 142:623-625.

Debbie, P., K. Young, L. Pooler, C. Lamp, P. Marietta, and R. Wagner. 1997. Allele identification using immobilized mismatch binding protein: Detection and identification of antibiotic-resistant bacteria and determination of sheep susceptibility to scrapie. Nucleic Acids Res. 25:4825-4829.

Gombojav, A., N. Ishiguro, M. Horiuchi, D. Serjmyadag, B. Byambaa, and M. Shinagawa. 2003. Amino acid Polymorphisms of PrP gene in Mongolian sheep. J. Vet. Med. Sci. 65:75-81.

NIAA. 2004. A guide to the national scrapie eradication program for veterinarians. Natl. Inst. Anim. Agric., Bowling Green, KY. Available: www.animalagriculture.org/scrapie/NIAA\%20Producer\%20kit.pdf. Accessed March 29, 2004.

O’Rourke, K. I., R. P. Melco, and J. R. Mickelson. 1996. Allelic frequencies of an ovine scrapie susceptibility gene. Anim. Biotech. 7:155-162.

Prusiner, S. B. 1982. Novel proteinaceous infectious particles cause scrapie. Science 216:136-144.

Smit, M. A., N. E. Cockett, J. E. Beever, T. L. Shay, and S. L. Eng. 2002. Scrapie in sheep: A transmissible spongiform encephalopathy. Sheep Goat Res. J. 17:21-32.

Thorgeirsdottir, S., S. Sigurdarson, H. M. Thorisson, G. Georgsson, and A. Palsdottir. 1999. PrP gene polymorphism and natural scrapie in Icelandic sheep. J. Gen. Virol. 80:2527-2534.

Westaway, D., V. Zuliani, C. M. Cooper, M. Da Costa, S. Neuman, A. L. Jenny, L. Detwiler, and S. B. Prusiner. 1994. Homozygosity for prion protein alleles encoding glutamine-171 renders sheep susceptible to natural scrapie. Genes Dev. 8:959-969.

Wineland, N. E., L. Detwiler, and D. Salmon. 1998. Epidemiologic analysis of reported scrapie in sheep in the United States: 1,117 cases (1947-1992). J. Am. Vet. Med. Assoc. 212:713-718. 